\title{
Sistem Pendukung Keputusan Penyeleksian Calon Peserta Olimpiade Menggunakan Metode SAW (Studi Kasus : SMAN 1 Beber Kabupaten Cirebon)
}

\author{
M Fizarudin ${ }^{1}$, R.Moh. Herdian Bhakti*2, \\ ${ }^{1}$ Sistem Informasi, STIKOM Poltek, Cirebon, Indonesia \\ ${ }^{* 2}$ Teknik Informatika, Universitas Muhadi Setiabudi, Brebes, Indonesia \\ e-mail corresponden*: herdian.bhakti@gmail.com
}

\begin{abstract}
Abstrak
Olimpiade Sains Nasional (OSN) merupakan kegiatan lomba bidang akademik yang diselenggarakan rutin setiap tahun. Kendala dalam proses penyeleksian calon peserta OSN di SMAN 1 Beber Kabupaten Cirebon yaitu merasa kesulitan dalam menseleksi cabang olimpiade kebumian, terkadang pihak sekolah dalam memilih calon peserta tidak sepenuhnya melihat kriteria yang ditetapkan. Metode yang digunakan dalam penelitian ini adalah SAW, metode ini dipilih karena dalam perhitungan normalisasi matriks sudah disesuaikan dengan jenis atribut pada masing-masing kriteria. Kriteria yang digunakan dalam penelitian ini berjumlah 7 kriteria. Berdasarkan hasil perhitungan alternatif terhadap kriteria didapatkan bahwa rangking pertama memiliki nilai $V$ sebesar 0,940; sedangkan urutan kedua memiliki nilai $V$ 0,936; urutan ketiga $V=0,826$; urutan keempat $V=0,792$; dan urutan kelima dengan $V=0,789$
\end{abstract}

Kata kunci-OSN, SPK, SAW

\begin{abstract}
The National Science Olympiad (OSN) is one of the academic field competitions held every 1 year. The obstacle in the process of selecting prospective OSN participants at SMAN 1 Beber, Cirebon Regency, namely the need to find prospective participants for the Earth Olympiad branch, sometimes the school in selecting candidates did not fully see the criteria set. The method used in this study is SAW, this method was chosen because the calculation of matrix normalization has been adjusted to the type of attribute in each criterion. The criteria used in this study amounted to 7 criteria. Based on the results of alternative calculations against the criteria it was found that the first rank has a V value of 0.940; while the second order has a $V$ value of 0.936; third order $V=0.826$; fourth order $V=0.792$; and fifth place with $V=0.789$
\end{abstract}

Keywords-OSN, decision support system, SAW

\section{PENDAHULUAN}

Olimpiade sains nasional adalah kegiatan lomba di bidang akademik yang diselenggarakan oleh Kementrian Pendidikan dan kebudayaan dalam rangka penuntasan wajib belajar yang bermutu. Penyelenggaraan olimpiade sains nasional bertujuan untuk membuat atmosfer kompetensi yang sehat dan mendorong sekolah untuk berperan dalam membimbing siswa agar meningkatkan kemampuan akademis pada berbagai bidang mata pelajaran[1]. SMA Negri 1 Beber adalah salah satu sekolah menengah atas negri yang berada di Kabupaten Cirebon yang setiap tahunnya selalu mengirimkan siswa terbaiknya untuk mengikuti kejuaraan OSN tingkat Kabupaten Cirebon. Berdasarkan pengalaman tahun sebelumnya kekurangan dalam proses penyeleksian calon peserta yang dilakukan oleh pihak sekolah masih berdasarkan peringkat dan nilai akademis. Dalam pengambilan keputusan pada dasarnya adalah pemilihan dari berbagai kriteria keputusan yang mungkin dipilih melalui proses terstruktur. Sama halnya

Submitted: 15 April 2019, Accepted: 29 April 2019, Published: Mei 2019

ISSN: 2685-4902 (online), Website: http://jurnal.umus.ac.id/index.php/intech 
seperti penyeleksian peserta OSN tingkat kabupaten, dimana diperlukan analisa yang tepat sehingga pemilihan calon peserta dapat benar-benar tepat. Selain itu, permasalahan yang sering dihadapi oleh pihak sekolah adalah dalam menentukan peserta untuk mengikuti cabang olimpiade kebumian. Dimana

Pembahasan mengenai pemilihan peserta dalam mengikuti berbagai lomba pernah dilakukan oleh beberapa peneliti seperti, Simple Additive Weight (SAW) dapat digunakan untuk menentukan Peserta Lomba Kompetensi Siswa (LKS) tingkat Sekolah Menengah Kejuruan (SMK) di Palangkaraya. SAW digunakan untuk menseleksi siswa terbaik dari seluruh pendaftar yang selanjutnya akan diikutkan lomba. Selanjutnya siswa yang lolos seleksi akan dilakukan pembinaan sebelum diikutkan lomba sampai ketingkat nasional[2]. Penelitian lain yang penulis jadikan acuan adalah penggunaan SAW dalam pemilihan kelayakan tempat praktek kerja industri untuk Sekolah Menengah Kejuruan. Kegiatan ini digunakan untuk meningkatkan keterampilan kompetensi peserta didik dalam angkatan kerja berdasarkan keahlian masingmasing peserta program. Kelayakan industri pelatihan kerja yang dituju dalam penelitian ini ditentukan oleh penyelarasan keahlian kompetensi pada industri pelatihan kerja dengan keahlian program peserta dan kriteria pendukung lainnya[3]. Kriteria yang dapat digunakan untuk menentukan proses penentuan peserta olimpiade sains adalah peringkat rangking, nilai rata-rata fisika, nilai rata-rata kimia, nilai rata-rata matematika dan nilai rata-rata kepribadian[4]. Berbeda halnya dengan kriteria-kriteria tersebut, maka pada penelitian ini peneliti menggunakan kriteria berupa nilai raport, rangking, nilai tes, kemampuan bahasa inggris, nilai kedisiplinan, nilai wawancara, serta pengalaman dalam mengikuti OSN. Selain menggunakan metode SAW, proses pemilihan peserta olimpiade matematika juga dapat menggunakan metode elektre dengan kriteria: nilai rata-rata, nilai matematika, keterampilan, perilaku, serta kehadiran. Berbeda dengan SAW, metode elektree ini akan dipengaruhi oleh tipe preferensi yang digunakan namun metode elektre hanya cocok digunakan untuk kasus yang memiliki banyak alternatif namun hanya sedikit kriteria yang dilibatkan[5]. Pada penelitian ini, peneliti memilih metode SAW karena bila dibandingkan dengan model pengambilan keputusan yang lain, maka metode SAW memiliki penilaian yang lebih tepat karena didasarkan pada nilai kriteria dan bobot preferensi yang sudah ditentukan, kemudian dilanjutkan dengan proses perangkingan yang akan menyeleksi alternatif terbaik dari sejumlah alternatif yang ada[6].

\section{METODE PENELITIAN}

\subsection{Deskripsi sistem}

Adapun uraian prosedur pemilihan tahap awal yaitu:

a. Setiap guru mata pelajaran yang diperlombakan akan memilih calon peserta sebanyak 5 siswa, yang nantinya akan menjalani tahap karantina dan penyeleksian.

b. Setelah menentukan calon peserta, setiap guru mata pelajaran akan menyerahkan formulir data calon peserta OSN kepada wakil kepala sekolah bidang kesiswaan

c. Wakil kepala sekolah bidang kesiswaan akan merekap nama calon peserta dan menyerahkannya kepada wakil sekolah bidang kurikulum.

d. Wakil kepada sekolah bidang kesiswaan akan mencetak form penilaian dan absensi karantina dan menyerahkannya kepada guru pembimbing.

e. Setelah ditandatangani siswa untuk setiap pertemuan selama 1 bulan, selanjutnya guru akan melakukan wawancara, tes soal, menilai sikap, kedisiplinan dan kerapihan calon peserta.

f. Guru akan merekap hasil penelitian tes dan membuat laporan penilaian karantina kepada wakil kepala sekolah bidang kesiswaan.

g. Selanjutnya wakil kepala sekolah bidang kesiswaan akan melakukan penyeleksian berdasarkan data siswa, nilai akademis dan hasil laporan penilaian karantina. 


\subsection{Simple Additive Weight (SAW)}

Metode SAW merupakan salah satu metode yang paling terkenal dan paling banyak digunakan dalam menghadapi situasi Multi Attribute Decission Making (MADM). MADM itu sendiri merupakan suatu metode yang digunakan mencari alternatif optimal dari sejumlah alternatif dengan kriteria tertentu[2]. Selain itu, metode SAW sering juga dikenal dengan istilah metode penjumlahan terbobot dimana konsep dasar metode SAW adalah mencari penjumlahan terbobot dari rating kinerja pada setiap alternatif di semua atribut, adapun kriteria penilaian dapat ditentukan sendiri sesuai dengan kebutuhan perusahaan[7].

Metode SAW mengenal adanya 2 atribut yaitu kriteria keuntungan (benefit) dan kriteria biaya (cost). Perbedaan mendasar dari kedua kriteria ini adalah dalam pemilihan kriteria ketika mengambil keputusan[8]

Adapun persamaan untuk melakukan normalisasi data adalah sebagai berikut:[9]

$$
\boldsymbol{r}_{i j}=\left\{\begin{array}{l}
\frac{\boldsymbol{x}_{i j}}{\boldsymbol{M A X}_{\left(x_{i j}\right)}} \text { Jika j adalah atribut keuntungan (benefit) } \\
\boldsymbol{i} \\
\frac{\boldsymbol{M I N}_{\left(x_{i j}\right)}}{\boldsymbol{x}_{i j}} \text { jika j adalah atribut biaya (cost) }
\end{array}\right.
$$

Dengan $\mathrm{r}_{\mathrm{ij}}$ adalah rating kinerja ternormalisasi dari alternatif $\left(A_{i}\right)$ pada atribut $\mathrm{C}_{\mathrm{j}}$; $\mathrm{i}=1,2, \ldots, \mathrm{m}$ dan $\mathrm{j}=1,2, \ldots, \mathrm{n}$. Sedangkan nilai preferensi untuk setiap alternatif (Vi) diberikan seperti yang ditunjukkan persamaan (2).

$$
V_{i}=\sum_{j=1}^{n} W_{j} r_{i j}
$$

Dengan:

$\mathrm{V}_{\mathrm{i}} \quad$ : nilai akhir dari alternatif

$\mathrm{W}_{\mathrm{j}} \quad$ : bobot yang telah ditentukan

$\mathrm{R}_{\mathrm{ij}} \quad$ : normalisasi matrik

i : alternatif

j : kriteria

n : banyaknya data

Nilai $\mathrm{V}_{\mathrm{i}}$ yang lebih besar mengidentifikasikan bahwa alternatif $\left(A_{i}\right)$ lebih terpilih. Berikut ini adalah tahapan-tahapan dalam menggunakan metode SAW:

a. Menentukan kriteria yang akan dijadikan acuan dalam pengambilan keputusan $\mathrm{C}_{\mathrm{i}}$

b. Menentukan rating kecocokan setiap alternatif pada setiap kriteria.

c. Membuat matriks keputusan berdasarkan kriteria $\left(\mathrm{C}_{\mathrm{i}}\right)$, kemudian melakukan normalisasi atriks berdasarkan persamaan yang disesuaikan dengan jenis atribut sehingga diperoleh matriks ternormalisasi.

d. Hasil akhir diperoleh dari proses perangkingan yaitu penjumlahan dari perkalian matriks ternormalisasi $\mathrm{R}$ dengan bobot vektor sehingga diperoleh nilai terbesar yang dipilih sebagai alternatif terbaik $\left(A_{i}\right)$ sebagai solusi.

\subsection{Perancangan sistem}

Perancangan pada sistem ini meliputi pembuatan desain dengan menggunakan diagram-diagram yang ada didalam UML yang digunakan untuk menggambarkan dan membangun dokumen artifak dari software intensive sistem[10]. Diagram yang digunakan dalam peracangan penelitian ini menggunakan class diagram dan sequance diagram. Class 
diagram menggambarkan struktur sistem dari segi pendefinisian kelas-kelas yang akan dibuat untuk membangun sistem. Kelas memiliki apa yang disebut atribut dan metode atau operasi. Atribut merupakan variabel yang dimiliki oleh suatu class, sedangkan operasi atau metode adalah fungsi yang dimiliki oleh suatu kelas[11]

Gambar 1 adalah gambaran class diagram yang penulis gunakan dalam menggambarkan hubungan antar class dalam struktur sistem yang dibangun. Sistem yang dibangun akan melibatkan 3 user yaitu wakil kepala sekolah, guru, dan siswa. Adapun tugas atau tanggungjawab dari masing-masing user tersebut adalah:

a. Wakil kepala sekolah bidang kesiswaan

Memiliki tanggungjawab untuk menambah, mengubah dan menghapus data kriteria serta mencetak laporan hasil seleksi calon peserta OSN

b. Guru

Memiliki tanggungjawab untuk menambah, mengubah, dan menghapus data soal dan penilaian calon peserta OSN, dan

c. Siswa

Dapat melakukan menambah, mengubah serta menghapus data diri sebagai calon peserta OSN serta melihat hasil seleksi.

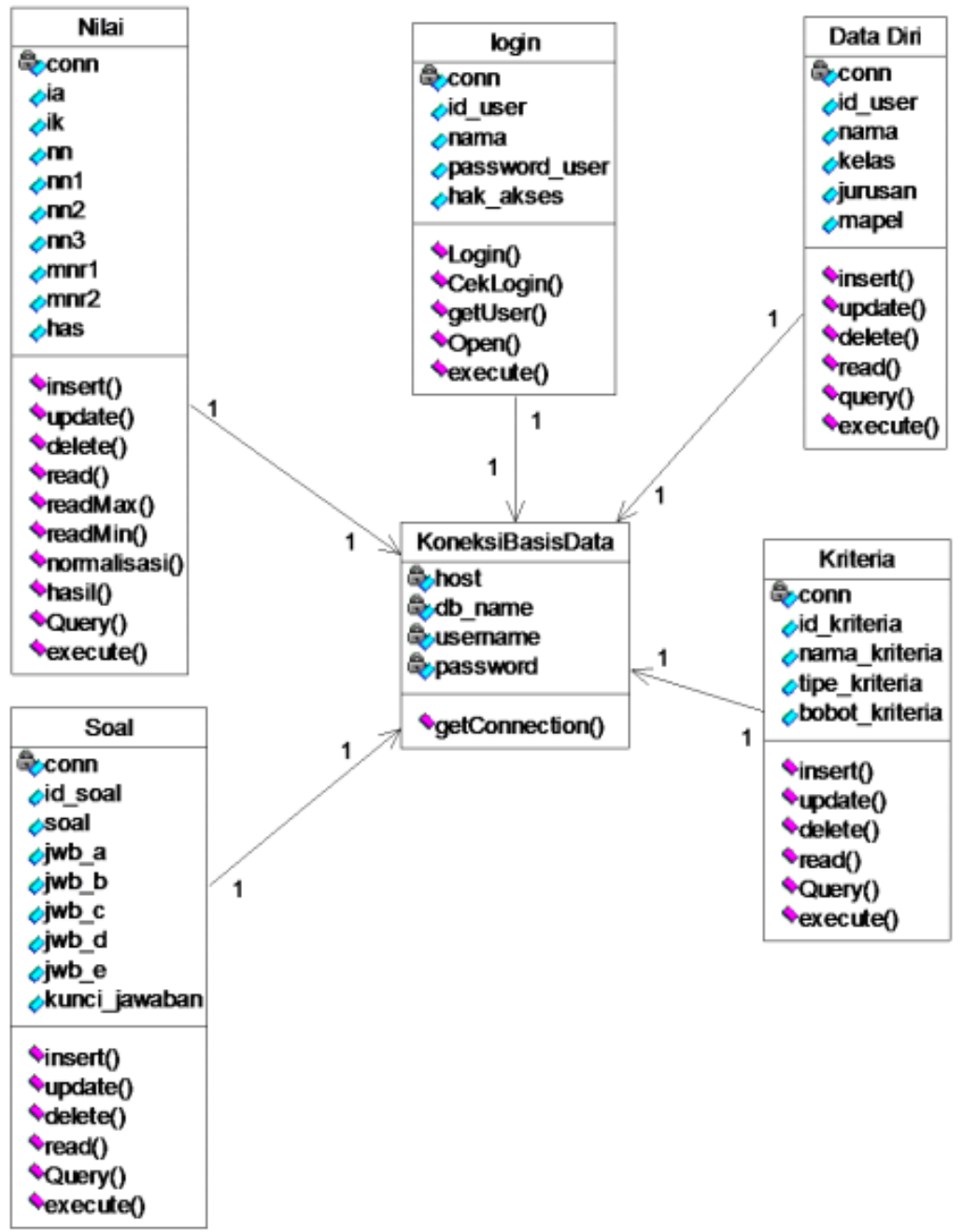

Gambar 1. Class diagram

Selain class diagram, penelitian ini juga menggnakan sequance diagram sebagai perancangan diagramnya. Pemodelan dengan menggunakan sequance diagram digunakan untuk menampilkan interaksi-interaksi antar obyek dalam sistem, termasuk pengguna, display, dan 
sebagainya berupa pesan atau penggambaran rangkaian langkah-langkah yang dilakukan sebagai sebuah respon dari suatu kejadian untuk menghasilkan output tertentu[12]. Gambaran sequance diagram pada sistem yang dibuat terdapat pada Gambar 2 dan Gambar 3

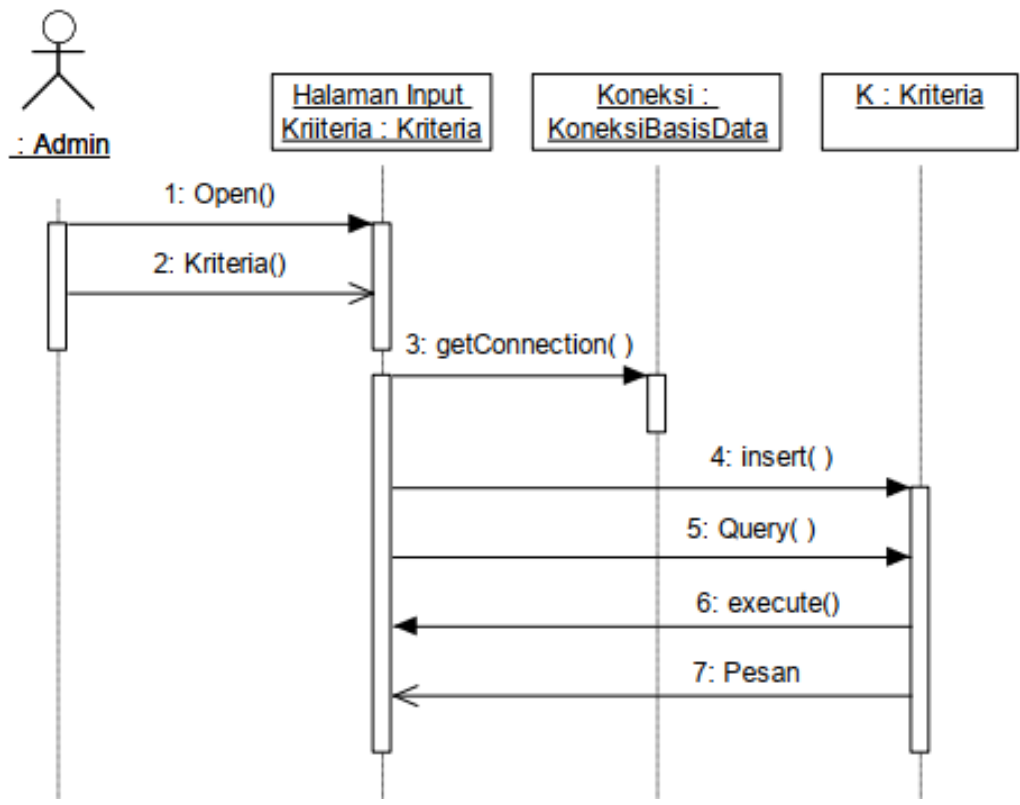

Gambar 2. Sequance diagram input data kriteria

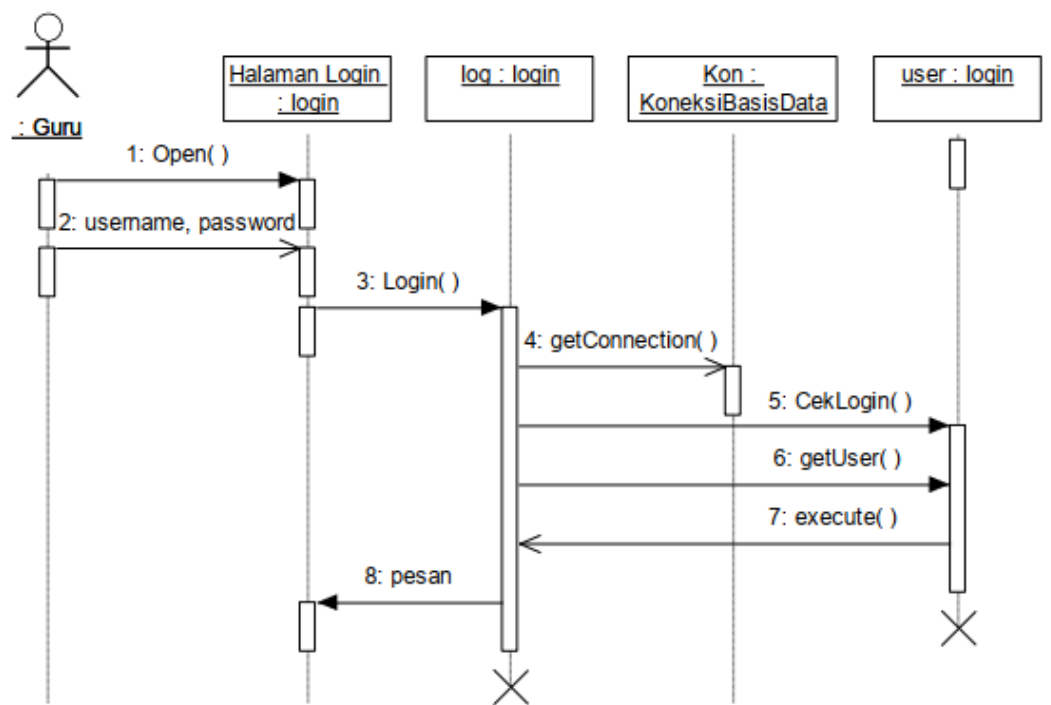

Gambar 3. Sequance diagram login guru

\section{HASIL DAN PEMBAHASAN}

\subsection{Penerapan SAW dalam kasus}

Beradasarkan hasil analisa pada Gambar 1, maka kriteria yang digunakan dalam penelitian berjumlah 7 kriteria. Adapun jenis kriteria dan nama kriteria tersebut terangkum pada Tabel 1.

Tabel 1. Kriteria dan jenis atributnya

\begin{tabular}{|c|c|}
\hline Nama kriteria & Jenis atribut \\
\hline Nilai rapot & Benefit \\
\hline
\end{tabular}




\begin{tabular}{|l|l|}
\hline Ranking & Cost \\
\hline Nilai tes & Benefit \\
\hline Kemampuan bahasa inggris & Benefit \\
\hline Nilai kedisiplinan & Benefit \\
\hline Nilai wawancara & Benefit \\
\hline Pengalaman mengikuti OSN & Benefit \\
\hline
\end{tabular}

Langkah selanjutnya yaitu menentukan bobot dari masing-masing kriteria yang telah ditentukan. Nilai dari bobot kriteria tersebut terlihat pada Tabel 2.

Tabel 2. Bobot kriteria

\begin{tabular}{|l|l|}
\hline \multicolumn{1}{|c|}{ Nama kriteria } & Bobot \\
\hline Nilai rapot & 0,15 \\
\hline Ranking & 0,1 \\
\hline Nilai tes & 0,15 \\
\hline Kemampuan bahasa inggris & 0,2 \\
\hline Nilai kedisiplinan & 0,1 \\
\hline Nilai wawancara & 0,1 \\
\hline Pengalaman mengikuti OSN & 0,2 \\
\hline
\end{tabular}

Selanjutnya menentukan rating kecocokan setiap alternatif pada setiap kriteria

a. Rentang nilai bobot kriteria kedisiplinan

Tabel 3. Bobot kriteria

\begin{tabular}{|l|c|}
\hline \multicolumn{1}{|c|}{ Nilai kedisiplinan } & Nilai \\
\hline Sangat baik & 3 \\
\hline Baik & 2 \\
\hline Cukup & 1 \\
\hline
\end{tabular}

b. Rentang nilai bobot kriteria pengalaman mengikuti OSN

Tabel 4. Rentang nilai bobot kriteria pengalaman mengikuti OSN

\begin{tabular}{|l|c|c|}
\hline Pengalaman Mengikuti OSN & Keterangan & nilai \\
\hline Juara & Sangat tinggi & 3 \\
\hline Pernah mengikuti & Cukup & 2 \\
\hline Belum pernah mengikuti & Rendah & 1 \\
\hline
\end{tabular}

Selanjutnya memasukkan data nilai awal calon peserta. Untuk lebih jelasnya tentang nilai awal calon peserta dapat dilihat pada Tabel 5 .

Tabel 5. Nilai awal calon peserta

\begin{tabular}{|l|c|c|c|c|l|c|l|}
\hline Alternatif & $\begin{array}{c}\text { Nilai } \\
\text { raport }\end{array}$ & Rangking & $\begin{array}{c}\text { Nilai } \\
\text { tes }\end{array}$ & $\begin{array}{c}\text { Bhs } \\
\text { inggris }\end{array}$ & Kedisiplinan & Wawancara & $\begin{array}{c}\text { Pengalaman } \\
\text { OSN }\end{array}$ \\
\hline $\begin{array}{l}\text { Budi } \\
\text { hartono }\end{array}$ & 80 & 3 & 78 & 82 & Sangat baik & 79 & $\begin{array}{l}\text { Belum } \\
\text { pernah }\end{array}$ \\
\hline $\begin{array}{l}\text { Elis } \\
\text { solihati }\end{array}$ & 85 & 2 & 80 & 80 & Baik & 80 & $\begin{array}{l}\text { Pernah } \\
\text { mengikuti }\end{array}$ \\
\hline $\begin{array}{l}\text { Yusup } \\
\text { imron }\end{array}$ & 85 & 4 & 82 & 88 & Sangat baik & 80 & $\begin{array}{l}\text { Pernah } \\
\text { mengikuti }\end{array}$ \\
\hline $\begin{array}{l}\text { Eha } \\
\text { soleha }\end{array}$ & 84 & 3 & 75 & 80 & Baik & 78 & $\begin{array}{l}\text { Belum } \\
\text { pernah } \\
\text { mengikuti }\end{array}$ \\
\hline \multicolumn{1}{c}{ Desi } & 86 & 4 & 77 & 81 & Baik & 89 & $\begin{array}{c}\text { Belum } \\
\text { pernah }\end{array}$ \\
\hline
\end{tabular}




\begin{tabular}{|l|l|l|l|l|l|l|}
\hline & & & & & & \\
mengikuti
\end{tabular}

Selanjutnya mengubah nilai awal sesuai dengan rentang bobot kriteria. Untuk lebih jelasnya tentang nilai awal yang diubah sesuai dengan rentang bobot kriteria dapat dilihat pada tabel 6.

Tabel 6. Nilai awal calon peserta sesuai rentang nilai kriteria

\begin{tabular}{|l|c|c|c|c|c|c|c|}
\hline Alternatif & $\begin{array}{c}\text { Nilai } \\
\text { raport }\end{array}$ & Rangking & $\begin{array}{c}\text { Nilai } \\
\text { tes }\end{array}$ & $\begin{array}{c}\text { Bhs } \\
\text { inggris }\end{array}$ & $\begin{array}{c}\text { Nilai } \\
\text { Kedisiplinan }\end{array}$ & Wawancara & $\begin{array}{c}\text { Nilai } \\
\text { Pengalaman } \\
\text { OSN }\end{array}$ \\
\hline $\begin{array}{l}\text { Budi } \\
\text { hartono }\end{array}$ & 80 & 3 & 78 & 82 & 3 & 79 & 1 \\
\hline $\begin{array}{l}\text { Elis } \\
\text { solihati }\end{array}$ & 85 & 2 & 80 & 80 & 2 & 80 & 2 \\
\hline $\begin{array}{l}\text { Yusup } \\
\text { imron }\end{array}$ & 85 & 4 & 82 & 88 & 3 & 80 & 2 \\
\hline Eha soleha & 84 & 3 & 75 & 80 & 2 & 78 & 1 \\
\hline Desi & 86 & 4 & 77 & 81 & 2 & 89 & 1 \\
\hline
\end{tabular}

Berdasarkan tabel 6, maka matriks keputusan yang dihasilkan adalah:

$\left(\begin{array}{llllccc}80 & 3 & 78 & 82 & 1 & 79 & 0 \\ 85 & 3 & 80 & 80 & 0,5 & 80 & 0,5 \\ 85 & 2 & 82 & 88 & 1 & 80 & 0,5 \\ 84 & 3 & 75 & 80 & 0,5 & 78 & 0 \\ 85 & 2 & 77 & 81 & 0,5 & 89 & 0\end{array}\right)$

Kriteria nilai raport:

$\mathrm{R}_{11}=80 / \max (80 ; 85 ; 85 ; 84 ; 85)=0,94$

$\mathrm{R}_{12}=85 / \max (80 ; 85 ; 85 ; 84 ; 85)=1$

$\mathrm{R}_{13}=85 / \max (80 ; 85 ; 85 ; 84 ; 85)=1$

$\mathrm{R}_{14}=84 / \max (80 ; 85 ; 85 ; 84 ; 85)=0,99$

$\mathrm{R}_{15}=86 / \max (80 ; 85 ; 85 ; 84 ; 85)=1$

Kriteria nilai rangking:

$\mathrm{R}_{21}=\min (3 ; 2 ; 4 ; 3 ; 4) / 3=0,67$

$\mathrm{R}_{22}=\min (3 ; 2 ; 4 ; 3 ; 4) / 2=1$

$\mathrm{R}_{23}=\min (3 ; 2 ; 4 ; 3 ; 4) / 4=0,5$

$\mathrm{R}_{24}=\min (3 ; 2 ; 4 ; 3 ; 4) / 3=0,67$

$\mathrm{R}_{25}=\min (3 ; 2 ; 4 ; 3 ; 4) / 4=0,5$

Kriteria nilai tes:

$\mathrm{R}_{31}=78 / \max (78 ; 80 ; 82 ; 75 ; 77)=0,95$

$\mathrm{R}_{32}=80 / \max (78 ; 80 ; 82 ; 75 ; 77)=0,98$

$\mathrm{R}_{33}=82 / \max (78 ; 80 ; 82 ; 75 ; 77)=1$

$\mathrm{R}_{34}=75 / \max (78 ; 80 ; 82 ; 75 ; 77)=0,91$

$\mathrm{R}_{35}=77 / \max (78 ; 80 ; 82 ; 75 ; 77)=0,94$

Dan selanjutnya, sehingga didapatkan nilai normalisasinya adalah:

$\left[\begin{array}{ccccccc}0,94 & 0,67 & 0,95 & 0,93 & 1 & 0,89 & 0,5 \\ 1 & 1 & 0,98 & 0,91 & 0,67 & 0,9 & 1 \\ & \\ \hline\end{array}\right.$


Proses perangkingan

$\begin{array}{ccccccc}1 & 0,5 & 1 & 1 & 1 & 0,9 & 1 \\ 0,99 & 0,67 & 0,91 & 0,91 & 0,67 & 0,88 & 0,5 \\ 1 & 0,5 & 0,95 & 0,92 & 0,67 & 1 & 0,5\end{array}$

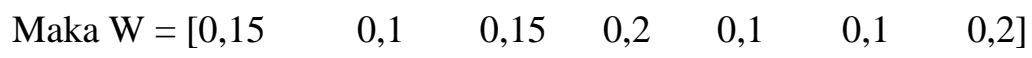

Dimana hasil akhir dari proses perangkingan alternatif adalah:

Tabel 7. Hasil akhir

\begin{tabular}{|l|c|c|}
\hline \multicolumn{1}{|c|}{ Nama siswa } & Hasil & Rangking \\
\hline Budi hartono & 0,826 & 3 \\
\hline Elis solihati & 0,936 & 2 \\
\hline Yusup imron & 0,940 & 1 \\
\hline Eha soleha & 0,789 & 5 \\
\hline Desi & 0,792 & 4 \\
\hline
\end{tabular}

\subsection{Pengujian black box}

Berikut ini adalah sebagian dari hasil pengujian blackbox berdasarkan menu yang peneliti lakukan:

a. Menu kriteria

Tabel 8. Pengujian blackbox menu kriteria

\begin{tabular}{|c|c|c|c|c|c|}
\hline No & Alur & Skenario & $\begin{array}{l}\text { Hasil yang } \\
\text { diharapkan }\end{array}$ & $\begin{array}{c}\text { Hasil } \\
\text { sebenarnya }\end{array}$ & Hasil uji \\
\hline 1 & $\begin{array}{l}\text { a. Membuka } \\
\text { menu kriteria } \\
\text { b. Klik tambah } \\
\text { kriteria }\end{array}$ & $\begin{array}{l}\text { Menambah } \\
\text { kriteria kedalam } \\
\text { database }\end{array}$ & $\begin{array}{l}\text { Menampilkan } \\
\text { pesan data } \\
\text { tersimpan }\end{array}$ & $\begin{array}{l}\text { Pesan data } \\
\text { tersimpan } \\
\text { tampil }\end{array}$ & Sesuai \\
\hline 2 & $\begin{array}{ll}\text { a. } & \text { Membuka } \\
& \text { menu kriteria } \\
\text { b. } & \text { Klik ubah } \\
\text { kriteria } & \\
\end{array}$ & $\begin{array}{l}\text { Merubah data } \\
\text { kriteria }\end{array}$ & $\begin{array}{l}\text { Menampilkan } \\
\text { pesan perubahan }\end{array}$ & $\begin{array}{l}\text { Pesan } \\
\text { perubahan } \\
\text { tampil }\end{array}$ & Sesuai \\
\hline 3 & $\begin{array}{ll}\text { a. } & \text { Membuka } \\
\text { menu kriteria } \\
\text { b. } \\
\text { Klik hapus } \\
\text { kriteria }\end{array}$ & $\begin{array}{l}\text { Menghapus data } \\
\text { kriteria }\end{array}$ & $\begin{array}{l}\text { Menampilkan } \\
\text { pesan } \\
\text { penghapusan }\end{array}$ & $\begin{array}{l}\text { Pesan } \\
\text { penghapusan } \\
\text { tampil }\end{array}$ & Sesuai \\
\hline
\end{tabular}

b. Menu penilaian

Tabel 9. Pengujian blackbox menu penilaian

\begin{tabular}{|c|ll|l|l|l|l|}
\hline No & \multicolumn{2}{|c|}{ Alur } & \multicolumn{1}{|c|}{ Skenario } & \multicolumn{1}{|c|}{$\begin{array}{c}\text { Hasil yang } \\
\text { diharapkan }\end{array}$} & \multicolumn{1}{c|}{$\begin{array}{c}\text { Hasil } \\
\text { sebenarnya }\end{array}$} & Hasil uji \\
\hline 1 & $\begin{array}{l}\text { Membuka menu } \\
\text { nilai }\end{array}$ & Menambah data & $\begin{array}{l}\text { Menampilkan } \\
\text { pesan }\end{array}$ & Pesan tambil & Sesuai \\
\hline 2 & $\begin{array}{l}\text { Membuka menu } \\
\text { ubah nilai }\end{array}$ & $\begin{array}{l}\text { Merubah data } \\
\text { nilai }\end{array}$ & $\begin{array}{l}\text { Menampilkan } \\
\text { pesan perubahan }\end{array}$ & $\begin{array}{l}\text { Pesan } \\
\text { perubahan } \\
\text { tampil }\end{array}$ & Sesuai \\
\hline 3 & $\begin{array}{l}\text { Membuka menu } \\
\text { hapus nilai }\end{array}$ & $\begin{array}{l}\text { Menghapus data } \\
\text { nilai }\end{array}$ & $\begin{array}{l}\text { Menampilkan } \\
\text { pesan } \\
\text { penghapusan }\end{array}$ & $\begin{array}{l}\text { Pesan } \\
\text { penghapusan } \\
\text { tampil }\end{array}$ & Sesuai \\
\hline
\end{tabular}

c. Menu hasil

Tabel 10. Pengujian blackbox menu hasil

\begin{tabular}{|l|l|l|l|l|l|}
\hline No & Alur & Skenario & Hasil yang & Hasil & Hasil uji \\
\hline
\end{tabular}




\begin{tabular}{|l|l|l|l|l|l|}
\hline 1 & & & \multicolumn{1}{|c|}{ diharapkan } & sebenarnya & \\
\hline $\begin{array}{l}\text { Membuka menu } \\
\text { hasil seleksi }\end{array}$ & $\begin{array}{l}\text { Melihat hasil } \\
\text { seleksi }\end{array}$ & $\begin{array}{l}\text { Menampilkan } \\
\text { data hasil } \\
\text { penyeleksian }\end{array}$ & $\begin{array}{l}\text { Menampilkan } \\
\text { data hasil } \\
\text { penyeleksian }\end{array}$ & Sesuai \\
\hline
\end{tabular}

\section{KESIMPULAN}

Berdasarkan hasil penelitian yang telah dilakukan oleh peneliti dapat disimpulkan bahwa metode SAW dapat digunakan untuk menghitung kriteria masing-masing siswa calon peserta OSN berdasarkan kriteria yang dimiliki. Berdasarkan 5 alternatif, maka didapatkan hasil bahwa nilai alternatif terbesar yaitu 0,940 yang akan menjadi alternatif pertama, 0,936 menjadi alternatif kedua, 0,826 yang akan menjadi alternatif ketiga, 0,792 yang akan menjadi alternatif keempat, dan 0,789 yang akan menjadi alternatif kelima.

\section{SARAN}

Untuk pengembangan lebih lanjut, maka penelitian ini memerlukan pengujian terhadap tingkat validasi data yang digunakan serta perhitungan kecocokan metode atau algoritma yang digunakan.

\section{DAFTAR PUSTAKA}

[1] Rianti. Eva., Pratama. RN, "Designing Application Decision Suppport System For Science Olympics Participants Election In SMPN Sijunjung Using Analytical Hierarchy Process Methods.” Jurnal Sains dan Informatika., Vol. 2, No. 2, p.49-60, Dec.2016 [Online]. Available http://ejournal.kopertis10.or.id/index.php/sains/article/view/1626/513.

[2] Widyaningsih. Maura., Giovanni. Leo, "Penentuan Peserta Lomba Kompetensi Siswa Menggunakan Simple Additive Weighting (SAW)." Jurnal Informatika dan Komputer., Vol. 1, No. 1, p.38-46, Feb.2016 [online]. Available : https://ejournal.akakom.ac.id/index.php/jiko/article/view/13/6

[3] Zubaeti. K.R et all, "Simple Additive Weighting Method in the Development of a System Assesing the Feasibility of Job Training Industry", Indonesian Journal of Informatics Education, Vol. 1, No. 2, p.17-28, Dec.2017 [online]. Available : https://jurnal.uns.ac.id/ijie/article/view/12332/pdf

[4] Situmorang. Harold, "Sistem Pendukung Keputusan Pemilihan Calon Peserta Olimpiade Sains Tingkat Kabupaten Langkat pada Madrasah Aliyah Negeri (MAN) 2 Tanjung Pura Dengan Menggunakan Metode Simple Additive Weighting (SAW)", Jurnal TIMES, Vol.IV No 2, p.24-30 [Online]. Available : http://www.stmiktime.ac.id/ejournal/index.php/jurnalTIMES/article/viewFile/230/94

[5] Sundari. S., et all, "Sistem Pendukung Keputusan Pemilihan Peserta Olimpiade Matematika SMA Swasta Teladan Pematangsiantar Dengan Metode Elektre", Seminar Nasional Teknologi Komputer dan Sains (SAINTEKS), Januari 2019, p.793-799 [Online], Available : http://seminar-id.com/prosiding/index.php/sainteks/article/download/233/228

[6] Nugroho. Setiya., Wulandari. FT., "Penerapan Metode MADM SAW Dalam Menentukan Produk Kerajinan Unggulan Kabupaten Klaten”, Jurnal Simetris Vol 7 No 1 April 2016, p.163-168

[Online]. Available 
http://jurnal.umk.ac.id/index.php/simet/article/download/500/535

[7] Frieyadie, "Penerapan Metode Simple Additive Weight (SAW) Dalam Sistem Pendukung Keputusan Promosi Kenaikan Jabatan”, Jurnal Pilar Nusa Mandiri Vol XII No.01 Maret 2016, p.37-45 [Online]. Available : https://media.neliti.com/media/publications/227474penerapan-metode-simple-additive-weight-4b140887.pdf

[8] Savitha. K., Chandrasekar. C., "Trusted Network Selection Using SAW and TOPSIS Algorithms for Heterogeneous Wireless Network", International Journal of Computer Applications (0975-8887) Volume 26 No.8 July 2011, p.22-29 [Online]. Available: https://pdfs.semanticscholar.org/75cc/20eac9d2599fe5312d98cac8ff82e4629614.pdf

[9] Alifah. W., et all, "Analisis Sistem Pendukung Keputusan Pemilihan Anggota Panitia Mahasiswa Baru (PMB) Dengan Metode SAW", Prosiding Seminar Nasional Inovasi Teknologi dan Ilmu Komputer (SNITIK), [Online] available : http://s3.amazonaws.com/assets.jurnal.unprimdn.ac.id/documents/post documents/c723e 5ac1011c78e90d7eef61708e94955583ad7.pdf

[10] Nugroho. KY, "Sistem Informasi Kemahasiswaan Fakultas Komunikasi dan Informatika Universitas Muhammadiyah Surakarta", Skripsi, Program Studi Informatika Fakultas Komunikasi dan Informatika Universitas Muhammadiyah Surakarta, 2016

[11] Heriyanto. Yunahar, "Perancangan Sistem Informasi Rental Mobil Berbasis Web Pada PT APM Rent Car", Jurnal Intra-Tech Volume 02 No.02 Oktober 2018, [Online] Available : http://journal.amikmahaputra.ac.id/index.php/JIT/article/download/35/29/

[12] Rusdiana. Lili, "Pemodelan Desain Sistem Informasi Pengolahan Data Produk Dekranasda Provinsi Kalimantan Tengah Menggunakan UML", Jurnal Informatika dan Komputer (JIKO) Vol. 01 No.01 Februari 2016, [Online] Available : https://ejournal.akakom.ac.id/index.php/jiko/article/view/12 